\title{
Epigenetics in Neurodevelopmental and Mental Disorders
}

\author{
Takeo Kubota Kunio Miyake Takae Hirasawa \\ Department of Epigenetic Medicine, Interdisciplinary Graduate School of Medicine and \\ Engineering, University of Yamanashi, Chuo, Japan
}

\section{Key Words}

Epigenetics - Neurodevelopmental disorder - Mental disorder - Environment · Rett syndrome . $\mathrm{MeCP} 2$

\begin{abstract}
Epigenetic mechanisms are essential for normal development during embryogenesis and for differentiation of neural cells. Thus, precise understanding of epigenetic mechanisms, including DNA methylation and histone modification, is important to elucidate the pathogenic pathways in neurodevelopmental disorders. These include various congenital disorders caused by failures of genomic imprinting, $X$ chromosome inactivation, and mutations of the proteins associated with epigenetic gene regulation. Several lines of evidence have suggested that various environmental factors, including insufficient nutrition, drugs, and mental stress, can alter epigenetic gene regulation in the brain, which potentially cause autism and adult mental disorders. However, epigenetic mechanisms are reversible mechanisms based on the attachment and detachment of modification factors onto DNA and histone proteins. Furthermore, recent studies indicate that epigenetic proteins, such as $\mathrm{MeCP2}$, act as 'lubricants' rather than essential parts that make up the brain structure, which works at a relatively later period of brain development. Therefore, making use of this epigenetic reversibility, the correction of abnormal epigenomic patterns and the administration or upregulation of epigenetic molecules will potentially be useful therapies for neurodevelopmental and mental disorders caused by epigenetic abnormalities.

(C) 2013 S. Karger AG, Basel
\end{abstract}

\section{Introduction}

The brain is a gene dosage-sensitive organ in which underexpression or overexpression of the same genes encoding proteins related to brain function results in a range of neurological disorders. The effects of aberrant gene expression are exemplified by conditions such 
as Pelizaeus-Merzbacher disease, a severe congenital disease associated with a deletion, mutation, or duplication of the proteolipid protein 1 (PLP1) gene [1], lissencephaly, a rare brain formation disorder associated with deletion or duplication of the platelet-activating factor acetylhydrolase 1B subunit alpha (PAFAH1B1) gene that encodes a neuronal migration factor [2, 3], Charcot-Marie-Tooth disease, an adult-onset neuromuscular disease associated with a mutation or duplication of the peripheral myelin protein 22 (PMP22) gene [4], and Parkinson's disease, which can have a mutation or multiplication of the $\alpha$-synuclein (SNCA) gene [5]. These clinical findings suggest that the brain is extremely sensitive to perturbations in gene regulation. Furthermore, they indicate that the brain is an organ that requires a proper control system for gene expression.

Epigenetic mechanisms are one of the ways by which gene expression is controlled in higher vertebrates. These mechanisms are essential for normal development during embryogenesis [6] and for differentiation of neural cells [7] and other cell types [8]. Understanding of epigenetic mechanisms, including DNA methylation, histone modification, and regulation by microRNAs, will be important for elucidating the pathogenic pathways in neurodevelopmental disorders [9-12].

In this short review, we provide a brief and basic description of congenital neurodevelopmental disorders caused by epigenetic abnormalities. Moreover, we also consider acquired neurodevelopmental disorders caused by environmentally induced epigenetic alterations. Finally, we discuss future directions in medicine for these disorders based on recent advances in our understanding of epigenetic mechanisms.

\section{Basic Mechanisms of Congenital Neurodevelopmental Mental Disorders Caused by Epigenetic Abnormalities}

The epigenetic phenomenon was initially discovered in humans through the studies of genomic imprinting. It is a parent-of-origin control of gene expression now known to be associated with various human disorders. In an imprinted gene, one of the two parental alleles is active and expressed and the other is inactive and not expressed. This difference in activity is based on differential epigenetic tagging of the alleles through a mechanism such as DNA methylation. Mutation or deletion of the active allele at an imprinted locus causes a failure of gene expression despite the presence of a normal gene at the inactive allele (fig. 1a). A classic example of this phenomenon occurs in the neurodevelopmental disorders Prader-Willi and Angelman syndromes [13].

Since the $\mathrm{X}$ chromosome carries more genes than the $\mathrm{Y}$ chromosome, females (XX) have more genes than males (XY). This potential sex-related imbalance in gene expression is avoided by the inactivation of one of the two X chromosomes in females through an epigenetic mechanism [14]. If X inactivation does not occur properly in a female fetus, the fetus dies in utero and is aborted (fig. 1b). The role of an epigenetic mechanism in the X inactivation is supported by the observation that cloned animals produced by somatic nuclear transfer abort their embryos following failure of the $\mathrm{X}$ chromosome inactivation $[15,16]$. Even if one of the $X$ chromosomes is extremely small due to large terminal deletions and the dosage effect of X-linked genes is small, the female fetus shows severe congenital neurodevelopmental delay [17]. This effect is further supported by the suggestion that proper epigenetic control of gene expression is essential for normal brain development.

DNA methylation is achieved by the addition of a methyl group $\left(\mathrm{CH}_{3}\right)$ to $\mathrm{CpG}$ dinucleotides in a reaction that is mediated by DNA methyltransferases. Defective activity of DNA (cytosine 5-)-methyltransferase 3 beta (DNMT3B) causes ICF syndrome, which is charac- 
Fig. 1. Epigenetic abnormalities associated with neurodevelopmental and mental diseases.

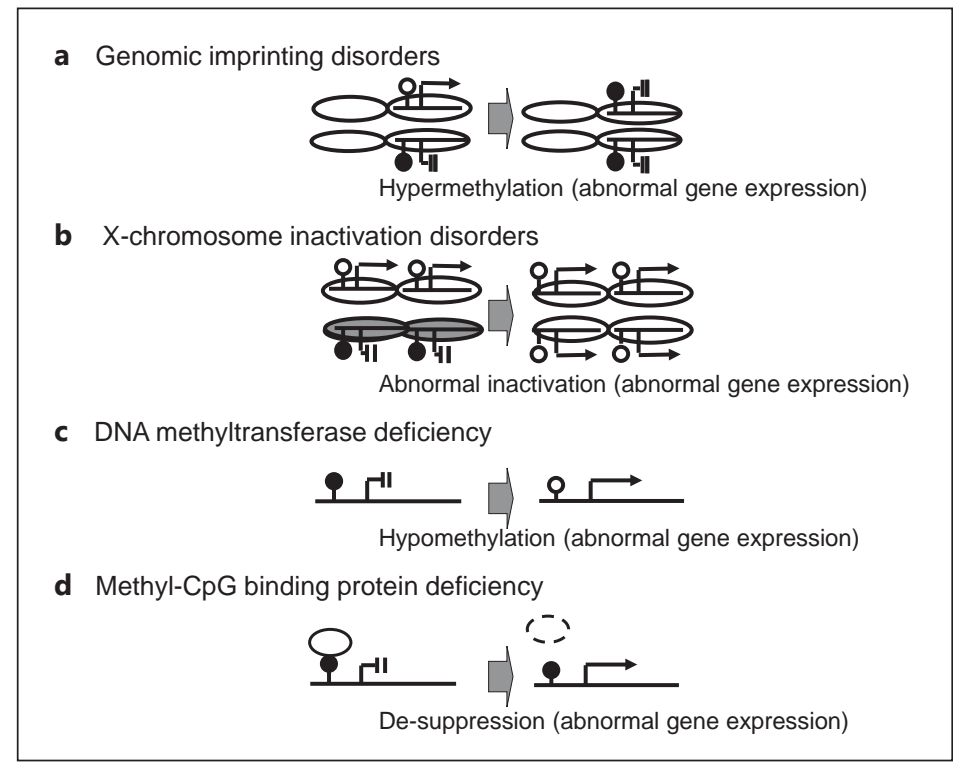

terized by immunodeficiency, centromere instability, facial anomalies, and mild mental retardation (fig. 1c) [18-20].

Methyl CpG-binding proteins, which bind to the methylated DNA region of genes, are also important molecules for control of gene expression. Mutations in the methyl CpG-binding protein 2 (MeCP2) gene cause Rett syndrome, which is characterized by seizures, ataxic gait, language dysfunction and autistic behavior [21, 22]. It is thought that mutation of $M e C P 2$ results in a dysfunctional protein, and the failure of MeCP2 to bind to the methylated regions of genes causes the inappropriate suppression of gene expression in the brain and leads to the manifestation of Rett syndrome (fig. 1d). Recent studies have shown that MeCP2 controls the expression of neuronal genes, such as brain-derived neurotrophic factor (BDNF), distalless homeobox 5 (DLX5), insulin-like growth factor-binding protein 3 (IGFBP3), and the protocadherins PCDHB1 and PCDH7 (neuronal cell adhesion molecules) [23-27]. These findings suggest that not only mutations [28], but also epigenetic dysregulation of genes encoding synaptic molecules is associated with the genesis of neurodevelopmental disorders. It has been found that both deficiency or excess of MeCP2, such as through duplication of the MECP2 genomic region, can lead to neuropsychiatric outcomes [29].

\section{Acquired Neurodevelopmental Disorders Caused by Environmentally Induced Epigenetic Alterations}

In England, the number of children with neurodevelopmental disorders, especially autistic spectrum disorder, has increased by 30 -fold (prevalence from $1 / 2,500$ to $1 / 86$ ) in the last 50 years [30]. Worldwide, the rate of affected children is currently estimated at 100 (range 34-264) per 10,000 children [31-35]. Therefore, precise understanding of the etiologies of these disorders is important.

Various environmental factors have been implicated as contributors to the pathogenesis of autistic spectrum disorder [36]. However, recent genetic studies in a subset of autistic children [28] have also revealed mutations in genes encoding proteins that are associated with synaptic function, including synaptic scaffolding proteins, receptors, transporters on 
Fig. 2. Current understanding of intrinsic and extrinsic factors that influence neurodevelopmental and mental diseases.

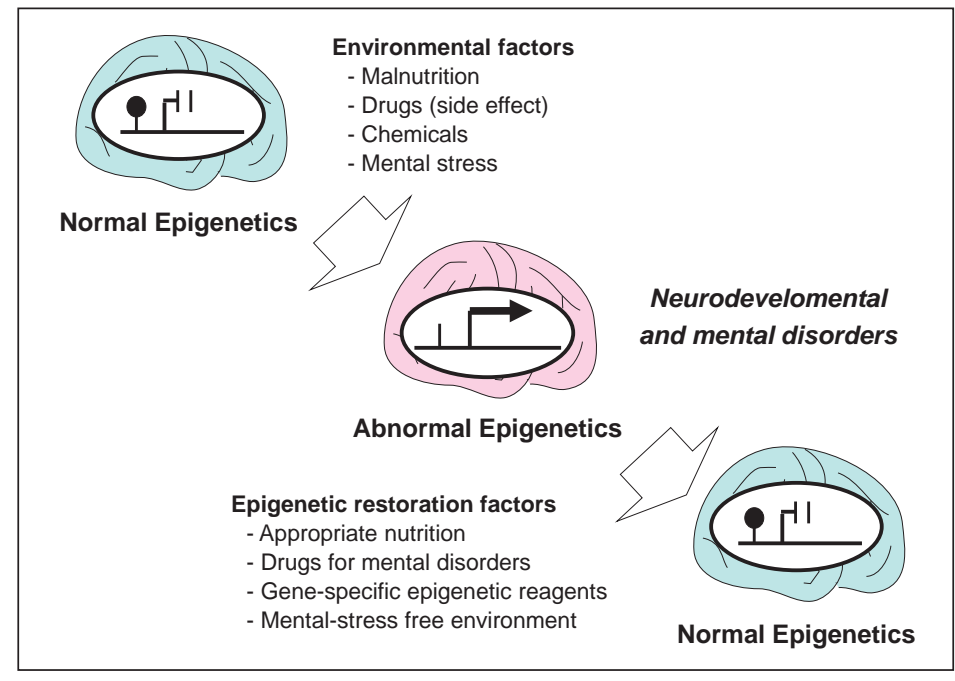

synapses and neuronal cell adhesion molecules. This evidence indicates that autism is a disorder of the synapse [37].

Nevertheless, the increase in the incidence of autism cannot be solely attributed to these genetic factors because it is unlikely that mutation rates have suddenly increased in the recent years. Therefore, environmental factors are more likely to be the cause of this increase. Some support for this conclusion comes from a study in twins that identified the influence of environmental factors on the occurrence of autism [38, 39].

Recent studies have shown that the epigenome (DNA and histone modifications) is more sensitive to environmental factors than the genome (DNA sequences) (fig. 2) [9]. Mental stress, such as maternal separation, changed the pattern of DNA methylation of the glucocorticoid receptor gene promoter in the mouse hippocampus during the first week of life [40]. Such environmentally induced DNA methylation changes can be transmitted across generations and induce abnormal behavior in later generations [41].

In humans, there is no direct evidence that environmental factors can alter the epigenomic status. However, older monozygotic twins have more epigenomic differences than their younger counterparts [41]. Likewise, in monozygotic twins with discordant severity of Rett syndrome, the epigenomic patterns of the twins differ and they show differences in the expression of neuronal genes [42]. This indicates that environmental factors may affect the human epigenome and that epigenomic differences induced by environmental factors may contribute to neurodevelopmental phenotypes.

In Japan, another social issue that may be related to epigenomic changes is the decline in birth weights during the past 20 years. This trend is thought to be a result of the popularity of dieting among young women and of the recommendation by obstetric physicians to minimize pregnancy weight gain in order to reduce the risk of gestational diabetes mellitus [43]. Based on current epidemiological studies of populations affected by famines in the Netherlands and China [43, 44], the generation with lower birth weight is expected to have an increased risk for obesity, diabetes mellitus and mental disorders in the future years in Japan; this is referred to as the Developmental Origin of Health and Diseases (DOHaD) [45, 46]. Recent studies have demonstrated that malnutrition during the fetal period causes a hypomethylation imprint on the peroxisome proliferator-activated receptor alpha (PPARa) gene in the rat liver [47]. Similar DNA methylation changes have been identified in the peripheral tissues of people who suffered malnutrition during a period of famine in the Netherlands [48]. 
It has also been reported that assisted reproductive technologies (for example, in vitro fertilization and intracytoplasmic sperm injection), which are now widely used due to increases in age at the time of marriage, decreased the status of DNA methylation at multiple maternally methylated imprinted loci $[49,50]$.

\section{The Future of Epigenetic Medicine for Neurodevelopmental Disorders}

It has been reported that administration of folic acid to pregnant rats alters the DNA methylation status in the offspring [51]. Another study has demonstrated that folic acid supplementation to pregnant rats under malnutrition conditions prevents hypomethylation of a hepatic gene in the offspring [52].

In addition to folic acid, a number of environmental factors, such as the nutritional supplement royal jelly [53], drugs for mental diseases [54-56], environmental chemicals [57, 58], and external stimuli (electroconvulsive treatment for psychiatric diseases) [59], have also been reported to alter DNA methylation or histone modification status in mice or other species.

As mentioned above, mental stress in the first week of life causes epigenetic abnormalities in the brains of mice. Conversely, several mouse studies have demonstrated that appropriate educational conditions may ameliorate features of neurodevelopmental disorders. In a mouse model of Rett syndrome, environmental enrichment, consisting of larger-sized home cages with a variety of objects, including running wheels, improved motor coordination and decreased anxiety-related behavior in heterozygous Mecp2+/- female mice [60, 61]. Environmental enrichment also improved locomotor activity with reduced ventricular volume, and restored the expression of synaptic markers, such as synaptophysin and PSD95 in the hypothalamus and syntaxin $1 \mathrm{~A}$ and synaptotagmin in the cortex of hemizygous Mecp2-/y male mice $[62,63]$.

It is generally thought to be difficult to cure patients with congenital neurodevelopmental disorders caused by mutations that encode neuronal molecules, since the distribution of gene products to the appropriate brain regions and at the appropriate time of brain development is complex. However, it has been recently demonstrated that the epigenetic disorder Rett syndrome may be an exception, partly because MeCP2 does not encode a product required for brain structure, but rather it encodes a 'lubricant' that works at a relatively late period of brain development. Therefore, reintroduction of MeCP2 into Mecp2 null mice not only before birth [64], but also after birth, is sufficient to resolve Rett-like neurological symptoms [65]. Furthermore, restoration of the MeCP2 function in astrocytes substantially improves locomotion, anxiety levels, and respiratory abnormalities in hemizygous Mecp2-/y male mice along with restoring dendritic morphology [66]. These results suggest that upregulation of $M E C P 2$, possibly mediated by drug treatment, might help to improve the brain function of Rett syndrome patients. Additionally, these results indicate that neurodevelopmental disorders caused by epigenetic abnormalities can be treatable.

\section{Acknowledgements}

The research described in this article was partially supported by the Ministry of Education, Science, Sports and Culture (MEXT), Grants-in-Aid (KAKENHI) for Scientific Research (A and B) (No. 23390272 to T.K.), Exploratory Research (No. 25670473 to T.K.), Young Scientists (B) (Nos. 23791156 and 25860852 to K.M.), Grant-in-Aid for Scientific Research on Innovative Areas 'Genome Science' (T.K.), and Scientific Research (C) (No. 23591491 to T.H.). 


\section{Disclosure Statement}

The authors have no relevant affiliations or financial involvement with any organization or entity with a financial interest in or financial conflict with the subject matter or materials discussed in the manuscript. This includes employment, consultancies, honoraria, stock ownership or options, expert testimony, grants or patents received or pending, or royalties. No writing assistance was utilized in the production of the manuscript.

\section{References}

1 Inoue K, Kanai M, Tanabe Y, Kubota T, Kashork CD, Wakui K, Fukushima Y, Lupski JR, Shaffer LG: Prenatal interphase FISH diagnosis of PLP1 duplication associated with Pelizaeus-Merzbacher disease. Prenat Diagn 2001;21:1133-1136.

- 2 Reiner O, Carrozzo R, Shen Y, Wehnert M, Faustinella F, Dobyns WB, Caskey CT, Ledbetter DH: Isolation of a Miller-Dieker lissencephaly gene containing G protein beta-subunit-like repeats. Nature 1993;364:717-721.

3 Bi W, Sapir T, Shchelochkov OA, Zhang F, Withers MA, Hunter JV, Levy T, Shinder V, Peiffer DA, Gunderson KL, Nezarati MM, Shotts VA, Amato SS, Savage SK, Harris DJ, Day-Salvatore DL, Horner M, Lu XY, Sahoo T, Yanagawa Y, Beaudet AL, Cheung SW, Martinez S, Lupski JR, Reiner O: Increased LIS1 expression affects human and mouse brain development. Nat Genet 2009;41:168-177.

4 Online Mendelian Inheritance in Man (OMIM): No. 118220. http://www.ncbi.nlm.nih.gov/entrez/.

5 Obi T, Nishioka K, Ross OA, Terada T, Yamazaki K, Sugiura A, Takanashi M, Mizoguchi K, Mori H, Mizuno Y, Hattori N: Clinicopathologic study of a SNCA gene duplication patient with Parkinson disease and dementia. Neurology 2008;70:238-241.

- 6 Li E, Beard C, Jaenisch R: Role for DNA methylation in genomic imprinting. Nature 1993;366:362-365.

- 7 Takizawa T, Nakashima K, Namihira M, Ochiai W, Uemura A, Yanagisawa M, Fujita N, Nakao M, Taga T: DNA methylation is a critical cell-intrinsic determinant of astrocyte differentiation in the fetal brain. Dev Cell 2001; 1:749-758.

8 Sakashita K, Koike K, Kinoshita T, Shiohara M, Kamijo T, Taniguchi S, Kubota T: Dynamic DNA methylation change in the CpG island region of p15 during human myeloid development. J Clin Invest 2001;108:11951204.

9 Qiu J: Epigenetics: unfinished symphony. Nature 2006;441:143-145.

10 Abel T, Zukin RS: Epigenetic targets of HDAC inhibition in neurodegenerative and psychiatric disorders. Curr Opin Pharmacol 2008;8:57-64.

11 Urdinguio RG, Sanchez-Mut JV, Esteller M: Epigenetic mechanisms in neurological diseases: genes syndromes and therapies. Lancet Neurol 2009;8:1056-1072.

12 Wu H, Tao J, Chen PJ, Shahab A, Ge W, Hart RP, Ruan X, Ruan Y, Sun YE: Genome-wide analysis reveals methylCpG-binding protein 2-dependent regulation of microRNAs in a mouse model of Rett syndrome. Proc Natl Acad Sci USA 2010;107:18161-18166.

-13 Kubota T, Das S, Christian SL, Baylin SB, Herman JG, Ledbetter DH: Methylation-specific PCR simplifies imprinting analysis. Nat Genet 1997;16:16-17.

-14 Kubota T, Nonoyama S, Tonoki H, Masuno M, Imaizumi K, Kojima M, Wakui K, Shimadzu M, Fukushima Y: A new assay for the analysis of X-chromosome inactivation based on methylation-specific PCR. Hum Genet 1999; 104:49-55.

-15 Xue F, Tian XC, Du F, Kubota C, Taneja M, Dinnyes A, Dai Y, Levine H, Pereira LV, Yang X: Aberrant patterns of $\mathrm{X}$ chromosome inactivation in bovine clones. Nat Genet 2002;31:216-220.

16 Nolen LD, Gao S, Han Z, Mann MR, Gie Chung Y, Otte AP, Bartolomei MS, Latham KE: X chromosome reactivation and regulation in cloned embryos. Dev Biol 2005;279:525-540.

17 Kubota T, Wakui K, Nakamura T, Ohashi H, Watanabe Y, Yoshino M, Kida T, Okamoto N, Matsumura M, Muroya K, Ogata T, Goto Y, Fukushima Y: Proportion of the cells with functional X disomy is associated with the severity of mental retardation in mosaic ring X Turner syndrome females. Cytogenet Genome Res 2002;99:276-284.

-18 Okano M, Bell DW, Haber DA, Li E: DNA methyltransferases Dnmt3a and Dnmt3b are essential for de novo methylation and mammalian development. Cell 1999;99:247-257.

19 Shirohzu H, Kubota T, Kumazawa A, Sado T, Chijiwa T, Inagaki K, Suetake I, Tajima S, Wakui K, Miki Y, Hayashi M, Fukushima Y, Sasaki H: Three novel DNMT3B mutations in Japanese patients with ICF syndrome. Am J Med Genet 2002;112:31-37.

20 Kubota T, Furuumi H, Kamoda T, Iwasaki N, Tobita N, Fujiwara N, Goto Y, Matsui A, Sasaki H, Kajii T: ICF syndrome in a girl with DNA hypomethylation but without detectable DNMT3B mutation. Am J Med Genet A 2004;129:290-293.

-21 Amir RE, Van den Veyver IB, Wan M, Tran CQ, Francke U, Zoghbi HY: Rett syndrome is caused by mutations in X-linked MECP2 encoding methyl-CpG-binding protein 2. Nat Genet 1999;23:185-188. 
22 Chunshu Y, Endoh K, Soutome M, Kawamura R, Kubota T: A patient with classic Rett syndrome with a novel mutation in MECP2 exon 1. Clin Genet 2006;70:530-531.

23 Chen WG, Chang Q, Lin Y, Meissner A, West AE, Griffith EC, Jaenisch R, Greenberg ME: Derepression of BDNF transcription involves calcium-dependent phosphorylation of MeCP2. Science 2003;302:885-889.

-24 Martinowich K, Hattori D, Wu H, Fouse S, He F, Hu Y, Fan G, Sun YE: DNA methylation-related chromatin remodeling in activity-dependent BDNF gene regulation. Science 2003;302:890-893.

25 Horike S, Cai S, Miyano M, Cheng JF, Kohwi-Shigematsu T: Loss of silent-chromatin looping and impaired imprinting of DLX5 in Rett syndrome. Nat Genet 2005;37:31-40.

26 Itoh M, Ide S, Takashima S, Kudo S, Nomura Y, Segawa M, Kubota T, Mori H, Tanaka S, Horie H, Tanabe Y, Goto Y: Methyl CpG-binding protein 2 whose mutation causes Rett syndrome directly regulates insulin-like growth factor binding protein 3 in mouse and human brains. J Neuropathol Exp Neurol 2007;66:117-123.

27 Miyake K, Hirasawa T, Soutome M, Itoh M, Goto Y, Endoh K, Takahashi K, Kudo S, Nakagawa T, Yokoi S, Taira T, Inazawa J, Kubota T: The protocadherins PCDHB1 and PCDH7 are regulated by MeCP2 in neuronal cells and brain tissues: implication for pathogenesis of Rett syndrome. BMC Neurosci 2011;12:81.

28 Persico AM, Bourgeron T: Searching for ways out of the autism maze: genetic, epigenetic and environmental clues. Trends Neurosci 2006;29:349-358.

29 Ramocki MB, Peters SU, Tavyev YJ, Zhang F, Carvalho CM, Schaaf CP, Richman R, Fang P, Glaze DG, Lupski JR, Zoghbi HY: Autism and other neuropsychiatric symptoms are prevalent in individuals with MeCP2 duplication syndrome. Ann Neurol 2009;66:771-782.

-30 Baird G, Simonoff E, Pickles A, Chandler S, Loucas T, Meldrum D, Charman T: Prevalence of disorders of the autism spectrum in a population cohort of children in South Thames: the Special Needs and Autism Project (SNAP). Lancet 2006;368:210-215.

-31 Yeargin-Allsopp M, Rice C, Karapurkar T, Doernberg N, Boyle C, Murphy C: Prevalence of Autism in a US Metropolitan Area. JAMA 2003;289:49-55.

-32 Honda H, Shimizu Y, Imai M, Nitto Y: Cumulative incidence of childhood autism: a total population study of better accuracy and precision. Dev Med Child Neurol 2005;47:10-18.

33 Holden C: Autism Now. Science 2009;323:565.

-34 Fombonne E: Epidemiology of pervasive developmental disorders. Pediatr Res 2009;65:591-598.

-35 Kim YS, Leventhal BL, Koh YJ, Fombonne E, Laska E, Lim EC, Cheon KA, Kim SJ, Kim YK, Lee H, Song DH, Grinker RR: Prevalence of autism spectrum disorders in a total population sample. Am J Psychiatry 2011;168:904912.

-36 Herbert MR: Contributions of the environment and environmentally vulnerable physiology to autism spectrum disorders. Curr Opin Neurol 2010;23:103-110.

-37 Zoghbi HY: Postnatal neurodevelopmental disorders: meeting at the synapse? Science 2003;302:826-830.

-38 Hoekstra RA, Bartels M, Hudziak JJ, Van Beijsterveldt TC, Boomsma DI: Genetics and environmental covariation between autistic traits and behavioral problems. Twin Res Hum Genet 2007;10:853-886.

-39 Hallmayer J, Cleveland S, Torres A, Phillips J, Cohen B, Torigoe T, Miller J, Fedele A, Collins J, Smith K, Lotspeich L, Croen LA, Ozonoff S, Lajonchere C, Grether JK, Risch N: Genetic heritability and shared environmental factors among twin pairs with autism. Arch Gen Psychiatry 2011;68:1095-1102.

40 Weaver IC, Cervoni N, Champagne FA, D'Alessio AC, Sharma S, Seckl JR, Dymov S, Szyf M, Meaney MJ: Epigentic programming by maternal behavior. Nat Neurosci 2004;9:847-854.

-41 Franklin TB, Russig H, Weiss IC, Gräff J, Linder N, Michalon A, Vizi S, Mansuy IM: Epigenetic transmission of the impact of early stress across generations. Biol Psychiatry 2010;68:408-415.

-42 Miyake K, Yang C, Minakuchi Y, Ohori K, Soutome M, Hirasawa T, Kazuki Y, Adachi N, Suzuki S, Itoh M, Goto Y, Andoh T, Kurosawa H, Oshimura M, Sasaki M, Toyoda A, Kubota T: Comparison of genomic and epigenomic expression in monozygotic twins discordant for Rett syndrome. PLoS One 2013;8:e66729.

43 Gluckman PD, Seng CY, Fukuoka H, Beedle AS, Hanson MA: Low birthweight and subsequent obesity in Japan. Lancet 2007;369:1081-1082.

44 Painter RC, de Rooij SR, Bossuyt PM, Simmers TA, Osmond C, Barker DJ, Bleker OP, Roseboom TJ: Early onset of coronary artery disease after prenatal exposure to the Dutch famine. Am J Clin Nutr 2006;84:322-327.

-45 St Clair D, Xu M, Wang P, Yu Y, Fang Y, Zhang F, Zheng X, Gu N, Feng G, Sham P, He L: Rates of adult schizophrenia following prenatal exposure to the Chinese famine of 1959-1961. JAMA 2005;294:557-562.

-46 Silveira PP, Portella AK, Goldani MZ, Barbieri MA: Developmental origins of health and disease (DOHaD). J Pediatr (Rio J) 2007;83:494-504.

-47 Lillycrop KA, Phillips ES, Torrens C, Hanson MA, Jackson AA, Burdge GC: Feeding pregnant rats a proteinrestricted diet persistently alters the methylation of specific cytosines in the hepatic PPAR alpha promoter of the offspring. Br J Nutr 2008;100:278-282.

$\checkmark 48$ Tobi EW, Lumey LH, Talens RP, Kremer D, Putter H, Stein AD, Slagboom PE, Heijmans BT: DNA methylation differences after exposure to prenatal famine are common and timing- and sex-specific. Hum Mol Genet 2009; 18:4046-4053.

49 Lim D, Bowdin SC, Tee L: Clinical and molecular genetic features of Beckwith-Wiedemann syndrome associated with assisted reproductive technologies. Hum Reprod 2009;24:741-747.

50 Bliek J, Alders M, Maas SM, Oostra RJ, Mackay DM, van der Lip K, Callaway JL, Brooks A, van't Padje S, Westerveld A, Leschot NJ, Mannens MM: Lessons from BWS twins: complex maternal and paternal hypomethylation and a common source of haematopoietic stem cells. Eur J Hum Genet 2009;17:1625-1634. 
51 Waterland RA, Jirtle RL: Transposable elements: targets for early nutritional effects on epigenetic gene regulation. Mol Cell Biol 2003;23:5293-5300.

52 Lillycrop KA, Phillips ES, Jackson AA, Hanson MA, Burdge GC: Dietary protein restriction of pregnant rats induces and folic acid supplementation prevents epigenetic modification of hepatic gene expression in the offspring. J Nutr 2005;135:1382-1386.

53 Kucharski R, Maleszka J, Foret S, Maleszka R: Nutritional control of reproductive status in honeybees via DNA methylation. Science 2008;319:1827-1830.

54 Tsankova NM, Berton O, Renthal W, Kumar A, Neve RL, Nestler EJ: Sustained hippocampal chromatin regulation in a mouse model of depression and antidepressant action. Nat Neurosci 2006;9:519-525.

55 Jessberger S, Nakashima K, Clemenson GD Jr, Mejia E, Mathews E, Ure K, Ogawa S, Sinton CM, Gage FH, Hsieh J: Epigenetic modulation of seizure-induced neurogenesis and cognitive decline. J Neurosci 2007;27:59675975.

-56 Dong E, Nelson M, Grayson DR, Costa E, Guidotti A: Clozapine and sulpiride but not haloperidol or olanzapine activate brain DNA demethylation. Proc Natl Acad Sci USA 2008;105:13614-13619.

57 Yaoi T, Itoh K, Nakamura K, Ogi H, Fujiwara Y, Fushiki S: Genome-wide analysis of epigenomic alterations in fetal mouse forebrain after exposure to low doses of bisphenol A. Biochem Biophys Res Commun 2008;376: 563-567.

-58 Gore AC, Walker DM, Zama AM, Armenti AE, Uzumcu M: Early life exposure to endocrine-disrupting chemicals causes lifelong molecular reprogramming of the hypothalamus and premature reproductive aging. Mol Endocrinol 2011;25:2157-2168.

59 Ma DK, Jang MH, Guo JU, Kitabatake Y, Chang ML, Pow-Anpongkul N, Flavell RA, Lu B, Ming GL, Song H: Neuronal activity-induced Gadd45b promotes epigenetic DNA demethylation and adult neurogenesis. Science 2009;323:1074-1077.

60 Kondo M, Gray LJ, Pelka GJ, Christodoulou J, Tam PP, Hannan AJ: Environmental enrichment ameliorates a motor coordination deficit in a mouse model of Rett syndrome - Mecp2 gene dosage effects and BDNF expression. Eur J Neurosci 2008;27:3342-3350.

61 Lonetti G, Angelucci A, Morando L, Boggio EM, Giustetto M, Pizzorusso T: Early environmental enrichment moderates the behavioral and synaptic phenotype of MeCP2 null mice. Biol Psychiatry 2010;67:657-665.

62 Nag N, Moriuchi JM, Peitzman CG, Ward BC, Kolodny NH, Berger-Sweeney JE: Environmental enrichment alters locomotor behaviour and ventricular volume in Mecp2 1lox mice. Behav Brain Res 2009;196:44-48.

63 Kerr B, Silva PA, Walz K, Young JI: Unconventional transcriptional response to environmental enrichment in a mouse model of Rett syndrome. PLoS One 2010;5:e11534.

64 Luikenhuis S, Giacometti E, Beard CF, Jaenisch R: Expression of MeCP2 in postmitotic neurons rescues Rett syndrome in mice. Proc Natl Acad Sci USA 2004;101:6033-6038.

65 Guy J, Gan J, Selfridge J, Cobb S, Bird A: Reversal of neurological defects in a mouse model of Rett syndrome. Science 2007;315:1143-1147.

66 Lioy DT, Garg SK, Monaghan CE, Raber J, Foust KD, Kaspar BK, Hirrlinger PG, Kirchhoff F, Bissonnette JM, Ballas N, Mandel G: A role for glia in the progression of Rett's syndrome. Nature 2011;475:497-500. 